\title{
Experience of online lecture delivery in a Nigerian university
}

\author{
E.O. Akinkunmi \\ Department of Pharmaceutics, Faculty of Pharmacy, Obafemi Awolowo University, Nigeria
}

\author{
Keywords \\ Nigeria \\ Online Lecture \\ Pharmacy Students \\ COVID-19
}

*Corresponding author:

eoakinmi@oauife.edu.ng
Summary: As COVID-19 continues to affect the global community, the ways in which stakeholders in pharmacy training respond to the 'new normal' will have long-lasting impact on the outcome of future pharmacists and the profession. This paper presents a report on the first-time experiment of using online lectures for some sets of students in a Nigerian pharmacy faculty. Challenges experienced during the lecture, as well as the suggestions and comments from students and faculties are included. It is evident that all stakeholders need to be carried along in designing the best way forward in pharmacy training in the present challenging times. It is concluded that online learning can offer an important alternative in resource limited settings, when all stakeholders are actively involved in its design.

\section{Background and Context}

The Obafemi Awolowo University was closed on 23rd March 2020 at the advent of the COVID-19 pandemic in Nigeria following the directive of Federal Ministry of Education, evidently based on the situation report from the Nigeria Centre for Disease Control (2020) and the World Health Organisation (2020). At that time, lectures were just starting in the Faculty of Pharmacy and some practical classes had also just commenced.

The University set up their own COVID-19 Task Force and announced on their website that any faculty members who were interested in offering virtual lectures should so indicate. Earlier, the Ministry of Education had asked universities to commence virtual learning. Individual universities, however, responded differently to this directive based on their particular situations.

The challenges which reportedly prevented many universities from following the directive included limited preparedness for online courses by the universities; the 'digital divide' that is affecting students living in unconnected areas; broad infrastructure challenges as required by virtual learning; lack of e-learning platforms and problems associated with handling large numbers of students online.
This report is a case study on the first time experience of online lectures by sets of students in a Nigerian pharmacy faculty, and the experience gained thereby with the proposal that online learning can offer an important alternative even in resource-limited settings in these challenging times (FIP, 2020; Petersen et al., 2020).

\section{Educational Description}

Preparations for the Class: On 22nd April 2020, the lecturer informed the class representatives for third and fourth year students via a phone call that he was planning to host their class lectures online. Previous to this, there had been earlier discussions on this subject with the class. The students expressed concern about the online format and asked questions related to it. A summary of the list of questions asked and the answers given are indicated in Table I. The lecturer sent the Zoom invites to the classes through their representatives on the 25th April 2020. A reminder was sent in the morning of the day of the first lecture.

Organisation of the Class: The programme started with two lectures both held on 27th April 2020. Third-year students had lectures on Pharmaceutical Microbiology I (Course Code 
PHA 302), whilst fourth-year students had lectures on Pharmaceutical Microbiology III (Code PHA 402). Each lecture lasted one hour. Table II shows some of the challenges encountered during the lectures and how they were addressed.

\section{Table I: List of questions and the answers given}

\begin{tabular}{lll}
\hline S/N & $\begin{array}{l}\text { List of questions asked by } \\
\text { students }\end{array}$ & Answers given by lecturer \\
\hline 1 & $\begin{array}{l}\text { How will those students } \\
\text { who don't have smart } \\
\text { phones participate? }\end{array}$ & $\begin{array}{l}\text { Since it is now an important } \\
\text { tool needed, students should } \\
\text { get it or use their computer }\end{array}$ \\
2 & $\begin{array}{l}\text { What will those who don't } \\
\text { have access to electricity to } \\
\text { charge phone or use } \\
\text { computer do? }\end{array}$ & $\begin{array}{l}\text { Students should charge their } \\
\text { phone full in readiness and } \\
\text { preparation for lecture }\end{array}$ \\
3 & $\begin{array}{l}\text { What happens to those who } \\
\text { are not financially buoyant } \\
\text { to get data? }\end{array}$ & $\begin{array}{l}\text { Each lecture will not cost up } \\
\text { to NGN500 (approximately }\end{array}$ \\
4 & $\begin{array}{l}\text { Will assessment be part of } \\
\text { the lecture? }\end{array}$ & $\begin{array}{l}\text { USD1.50) data } \\
\text { Assessment is a normal part } \\
\text { of lecture }\end{array}$ \\
5 & $\begin{array}{l}\text { Will attendance be taken? } \\
\text { Can the platform } \\
\text { accomodate the whole } \\
\text { class? }\end{array}$ & Yes \\
\hline
\end{tabular}

Table II: Challenges faced during the lecture and how they were addressed

\begin{tabular}{|c|c|c|}
\hline$S / N$ & Challenges & How they were Addressed \\
\hline 1 & $\begin{array}{l}\text { Disruptions in } \\
\text { network } \\
\text { and inability to link } \\
\text { up }\end{array}$ & $\begin{array}{l}\text { Most distruptions were corrected } \\
\text { when students changed their } \\
\text { location. Other option was that } \\
\text { students can change their network } \\
\text { provider. }\end{array}$ \\
\hline 2 & Noise & $\begin{array}{l}\text { Students made lots of noise as they } \\
\text { came to class and sometimes during } \\
\text { class. Simple solution is just to mute } \\
\text { them. }\end{array}$ \\
\hline 3 & Phone getting hot & $\begin{array}{l}\text { Some phones got hot after too long } \\
\text { continuous lecture. Participants } \\
\text { should not use such phone for more } \\
\text { than one hour lecture per time }\end{array}$ \\
\hline
\end{tabular}

Characteristics of the Class: There were options for video and audio interactions on the platform. During the course of the lectures, students were able to get their questions answered and assignments given.

\section{Outcomes and Recommendations}

Attendance: Over 90 students ( $\sim 53.6 \%$ ) out of a total of 168 registered and over 80 ( $\sim 63.0 \%)$ out of a total of 127 attended in third- and fourth-year classes respectively.

Evaluation of intervention: Evaluation was done by students through Google Forms. The following conclusions were derived from the students' responses:
1. Other platforms which may be cheaper alternatives and produce clearer broadcast, not necessarily with video, could be used.

2. More students prefer face to face to virtual lectures (54.5\%).

3. More students did not want the virtual learning to continue during lockdown (67.3\%) or when school finally resume (79.6\%).

4. More students believe that all identified challenges with virtual learning can be overcome (61.1\%).

Comments from other faculty members: The comments presented here are edited excerpts of very robust reactions and contributions on one of the WhatsApp groups for the faculty members.

1. There's absolutely nothing stopping lectures from being delivered online, except that practical exposure constitutes a substantial part of the Bachelor of Pharmacy programme, and there's no alternative to being physically on ground. Apart from this, the author believes universities will need to carefully assess the quality of lectures received online by the students since there is a higher chance of distraction specific to each student's immediate environment.

2. If nothing at all, this is something the faculty should definitely begin to explore as a mode of teaching, and for this the author expects the Faculty Board to have to consider all potential ramifications.

3. The author thinks this approach is quite innovative and knowledge gained from this experience will be useful.

4. Post-COVID-19 will be different to pre-COVID-19, universities should start preparing early for this new reality.

5. This was a very innovative experiment. Given that online lectures will soon be the norm in our Faculty, and the University as a whole, is a matter of time, the identified challenges notwithstanding.

\section{References}

FIP [International Pharmaceutical Federation]. (2020). Academic Pharmacy Section. The Mortar Board COVID-19 Special Edition. Available at: https://www.fip.org/files/content/priority-areas/ coronavirus/Other FIP resources/FIP AcPS-COVID-19 Special Edition-April 2020.pdf

Nigeria Centre for Disease Control. (2020). COVID-19 Situation Report. 23rd March 2020. Available at: https://covid19.ncdc.gov.ng

Petersen, E., Wasserman, S., Lee, S-S., Go, U., Holmes, A.H., Abri, S.A., McLellan, S., Blumberg, L., \& Tambyah, P. (2020). COVID-19-We urgently need to start developing an exit strategy, International Journal of Infectious Diseases, 96, 233-239. https://doi.org/10.1016/ j.ijid.2020.04.035

World Health Organisation. (2020). Coronavirus disease (COVID-2019) situation reports. WHO Coronavirus Disease (COVID-19). Available at: https://covid19.who.int/?gclid=EAlalQob ChMIx6aX2luq6wIVGZ3VCh1ocA-OEAAYASABEgILOfD BwE 